LUPININE ALKYL METHYLPHOSPHONATES

\title{
AND LUPININE DIETHYL PHOSPHOROTHIOATE
}

A.A. Abduvakhabov, Kh. A. Aslanov, A. S. Sadykov, and K. Inoyatova

UDC 1947

In order to determine their anticholinesterase activity, we have prepared phosphoric acid esters of lupinine. The lupinine was isolated by the sulfuric acid method from technical "anabasine sulfate" [1]; the alkyl methylphosphonochloridates and potassium diethyl phosphorothioate were obtained by published methods [2-4].

Ethyl Lupinine Methylphosphonate. Lupinine $(0.02$ mole) was added to a dispersion made by Brihl's method [5] of 0.02 g-atom of sodium in $70 \mathrm{ml}$ of absolute benzene. The mixture was boiled until the sodium had dissolved completely, and then 0.02 mole of ethyl methylphosphonochloridate was added over 5 min and the mixture was boiled again for $4 \mathrm{~h}$. Then it was decomposed with water and extracted with benzene. Aiter drying and the distillation of the solvent, the ethyl lupinine methylphosphonate $\mathrm{C}_{13} \mathrm{H}_{26} \mathrm{NO}_{3} \mathrm{P}$ was distilled in vacuum. Yield $30 \%$, bp $115^{\circ} \mathrm{C}$ at $4 \times 10^{-2} \mathrm{~mm}, \mathrm{~d}_{4}^{20}, 1.0856, \mathrm{n}_{\mathrm{D}}^{20} 1.4835$.

n-Butyl lupinine methylphosphonate $\mathrm{C}_{15} \mathrm{H}_{30} \mathrm{NO}_{3} \mathrm{P}$ was obtained similarly. Yield $35 \%$, bp $132-133^{\circ} \mathrm{C}$ at $1 \mathrm{~mm}, \mathrm{~d}_{4}^{20} 1.0596, \mathrm{n}_{\mathrm{D}}^{20} 1.4800$.

O,O-Diethyl S-Lupinine Phosphorothioate. With stirring, an ethanolic solution of $4 \mathrm{~g}(0.0174 \mathrm{~mole})$ of bromolupinane [6] in $10 \mathrm{ml}$ of ethanol was added to $3.34 \mathrm{~g}(0.0174$ mole) of potassium diethyl phosphorothioate in $15 \mathrm{ml}$ of absolute ethanol, and the reaction mixture was boiled for $5 \mathrm{~h}$. After $12 \mathrm{~h}$ the product was worked up in the usual way and distilled in vacuum. Yield $62 \%$, bp $113-114^{\circ} \mathrm{C}$ at $10^{-2} \mathrm{~mm}^{2} \mathrm{~d}_{4}^{20} 1.1217$, $\mathrm{n}_{\mathrm{D}}^{20} 1.5052, \mathrm{C}_{14} \mathrm{H}_{28} \mathrm{NO}_{3} \mathrm{PS}$.

The methiodides of $\mathrm{O}, \mathrm{O}$-diethyl S-lupinine phosphorothioate $\mathrm{C}_{10} \mathrm{H}_{18} \mathrm{NS}(\mathrm{O}) \mathrm{P}\left(\mathrm{OC}_{2} \mathrm{H}_{5}\right)_{2} \cdot \mathrm{CH}_{3} \mathrm{I}(\mathrm{yield} 90 \%$, $\mathrm{mp} 126^{\circ} \mathrm{C}$ ) and of n-butyl lupinine methylphosphonate $\mathrm{C}_{10} \mathrm{H}_{18} \mathrm{NO}(\mathrm{O}) \mathrm{P}\left(\mathrm{OC}_{4} \mathrm{H}_{9}\right) \mathrm{CH}_{3} \cdot \mathrm{CH}_{3} \mathrm{~J}\left(\mathrm{yield} 87 \%\right.$, mp $\left.150{ }^{\circ} \mathrm{C}\right)$ were obtained by the action of methyl iodide.

\section{LITERATURE C ITED}

1. A. S. Sadykov, The Chemistry of the Alkaloids of Anabasis aphylla [in Russian], Tashkent, 1956.

2. Methoden der Organischen Chemie, Phosphorverbindungen, Bd. XII/2, Berlin, 1963.

3. E. N. Tsvetkov and M. I. Kabachnik, Reaktsii i Methody Issledovaniya Organicheskikh Soedineni 1 , 13, 269,1964 .

4. G. Pesin and A. M. Khaletskii, ZhOKh, 31, 2511, 1961.

5. I. W. Brühl, Ber., 35, 3627, 1902 .

6. G. R. Clemo, W. Morgan, and R. Raper, J. Chem. Soc., 1937, 965.

Lenin Tashkent State University. Trans lated from Khimiya Prirodnykh Soedinenii, No. 6, pp. 771772, November-December, 1970. Original article submitted July 15, 1970.

- 1973 Consultants Bureau, a division of Plenum Publishing Corporation, 227 West 17th Street, New York, N. Y. 10011. All rights reserved. This article cannot be reproduced for any purpose whatsoever without permission of the publisher. A copy of this article is available from the publisher for $\$ 15.00$. 